\title{
Disassembly Intermediates of Brome Mosaic Virus Identified by Charge Detection Mass Spectrometry
}

\author{
Kevin M. Bond, Nicholas A. Lyktey, Irina B. Tsvetkova, \\ Bogdan Dragnea and Martin F. Jarrold
}

Chemistry Department, Indiana University, 800 E Kirkwood Ave, Bloomington, IN 47405

Supporting Information 
Figure S1. Plot showing how an almost Gaussian peak results from summing the peaks due to the three BMV components with different RNA content. Gaussian peaks for RNA1 (4.695 MDa), RNA2 (4.574 MDa), and RNA3/4 (4.615 MDa) are shown as the blue, yellow and green peaks. The full widths at half maximum of the peaks are given by the resolution of the CDMS measurements. The intensities are proportional to the median relative abundances of RNA1, RNA2, and RNA3/4 for BMV virions from Nicotiana benthamiana. The red peak shows the result of adding the three peaks together. The dashed black line shows the Gaussian peak that provides the best fit to the red peak.

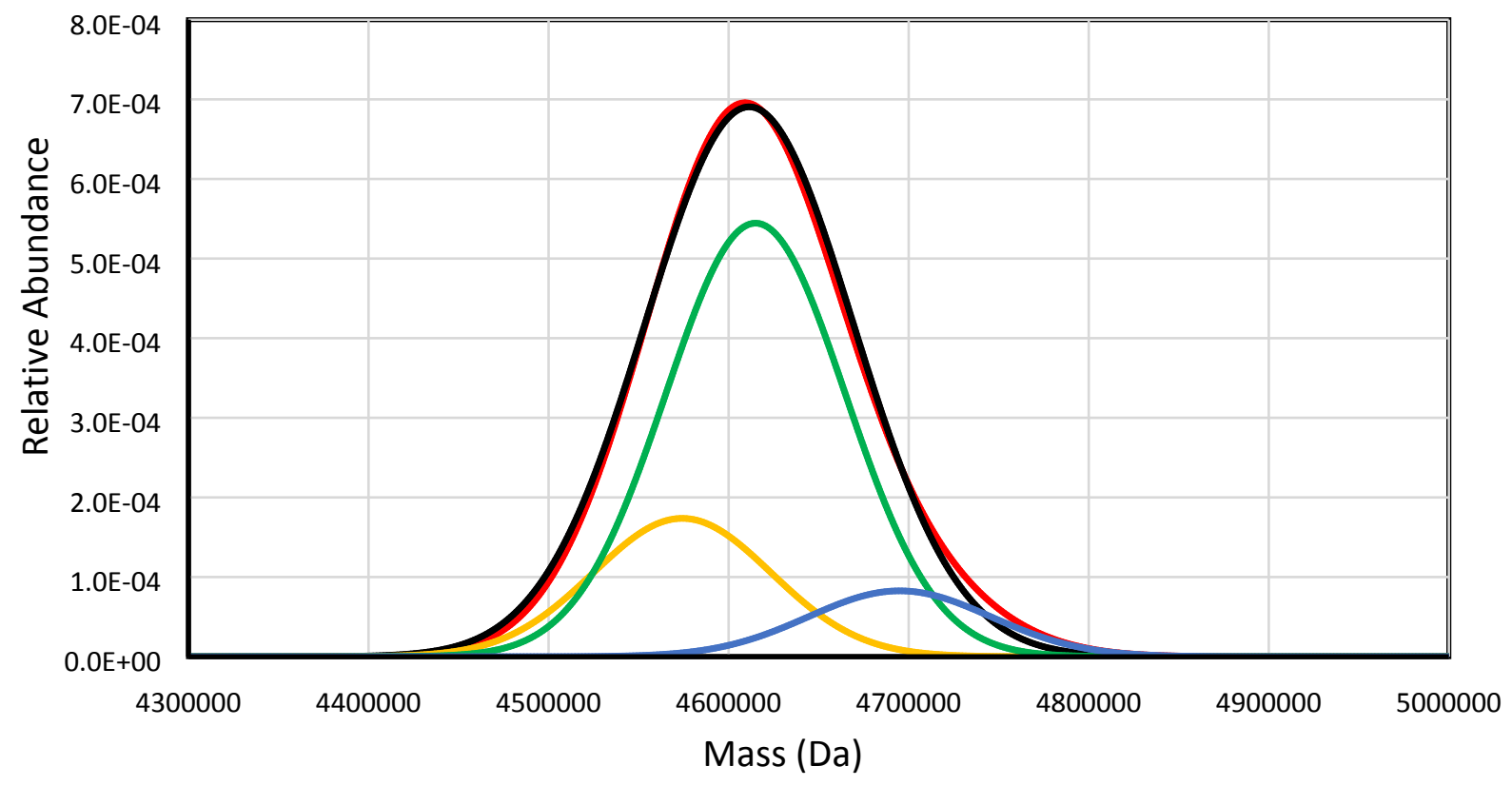


Figure S2. MALDI $\mathrm{m} / \mathrm{z}$ spectrum measured to determine whether the BMV capsid protein is degraded by the high $\mathrm{pH}$ conditions employed for virion disassembly. The BMV sample was buffer exchanged into $50 \mathrm{mM}$ ammonium acetate at a pH of 6-7. This solution was mixed in a $1: 1$ ratio with a $\mathrm{pH} 11$ solution of ammonium hydroxide in $50 \mathrm{mM}$ ammonium acetate. The resulting mixture (with a $\mathrm{pH}$ of around 10.3) was quenched with acetic acid after 2 minutes, and mixed with Sinapinic Acid matrix at a 1:5 ratio. A $1 \mathrm{uL}$ spot was deposited on the target and allowed to air dry. MALDI-TOF mass spectra were measured on a Bruker Autoflex III in the linear mode. A $355 \mathrm{~nm}$ frequency tripled $\mathrm{Nd}$-YAG laser was used for laser desorption. The peak at $20298 \mathrm{Da}$ in the spectrum is attributed to the singly charged capsid protein and the peak at $10148 \mathrm{Da}$ is attributed to doubly charged capsid protein. The results show that the capsid protein is not significantly degraded on the timescale of the measurements.

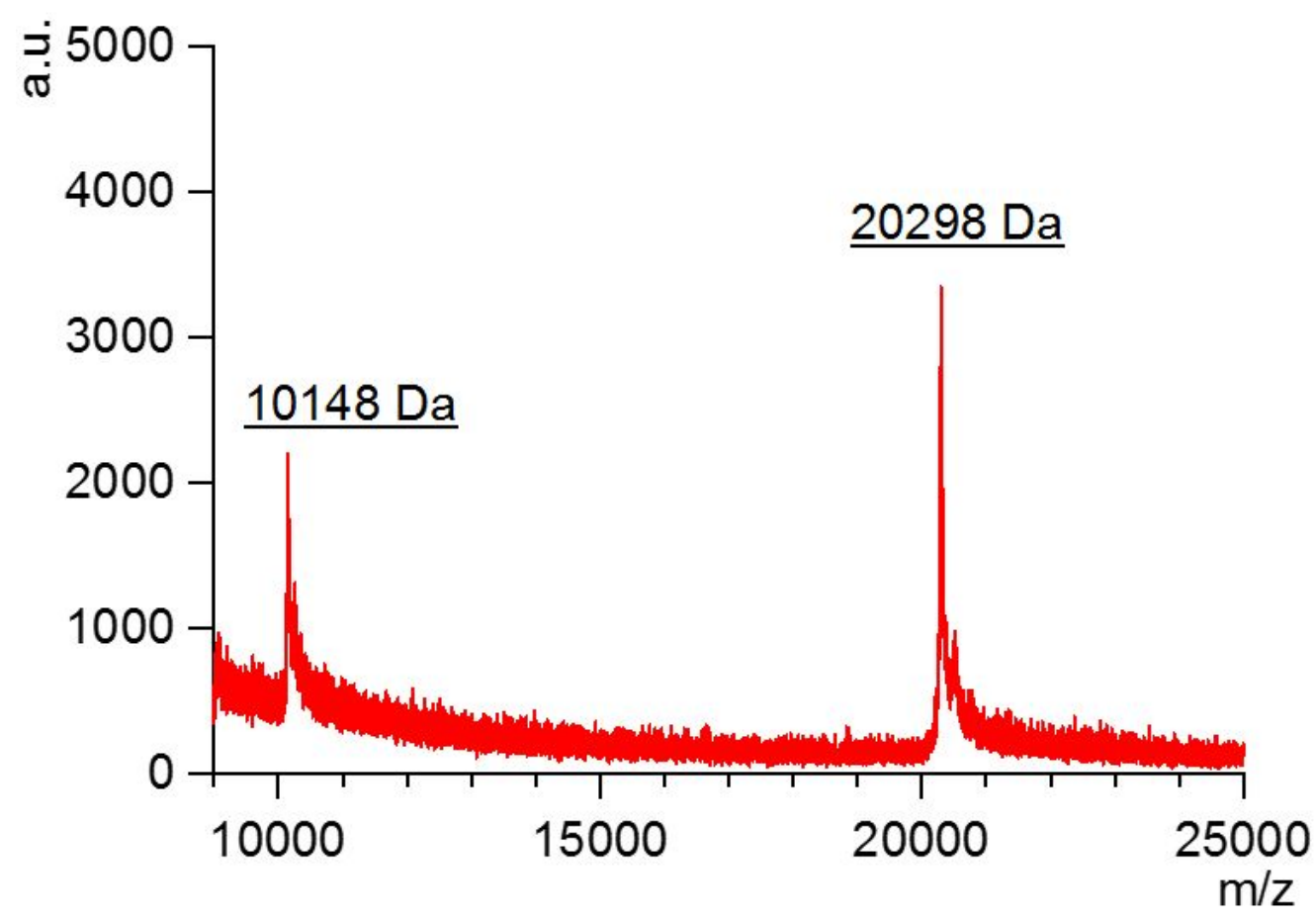


Figure S3. Agarose gel electrophoresis of RNAs extracted from BMV virions to determine whether the RNA is significantly degraded during exposure to the high $\mathrm{pH}$ conditions used for virion diassembly. Mixtures were prepared as described in the caption for Figure S2, and quenched at 30 seconds and 2 minutes. The RNA was then extracted using the standard phenol-chloroform protocol. The $\mathrm{pH}$ before quenching was 10.3. The results show that the RNA is not significantly degraded over the time scale of the disassembly experiments.

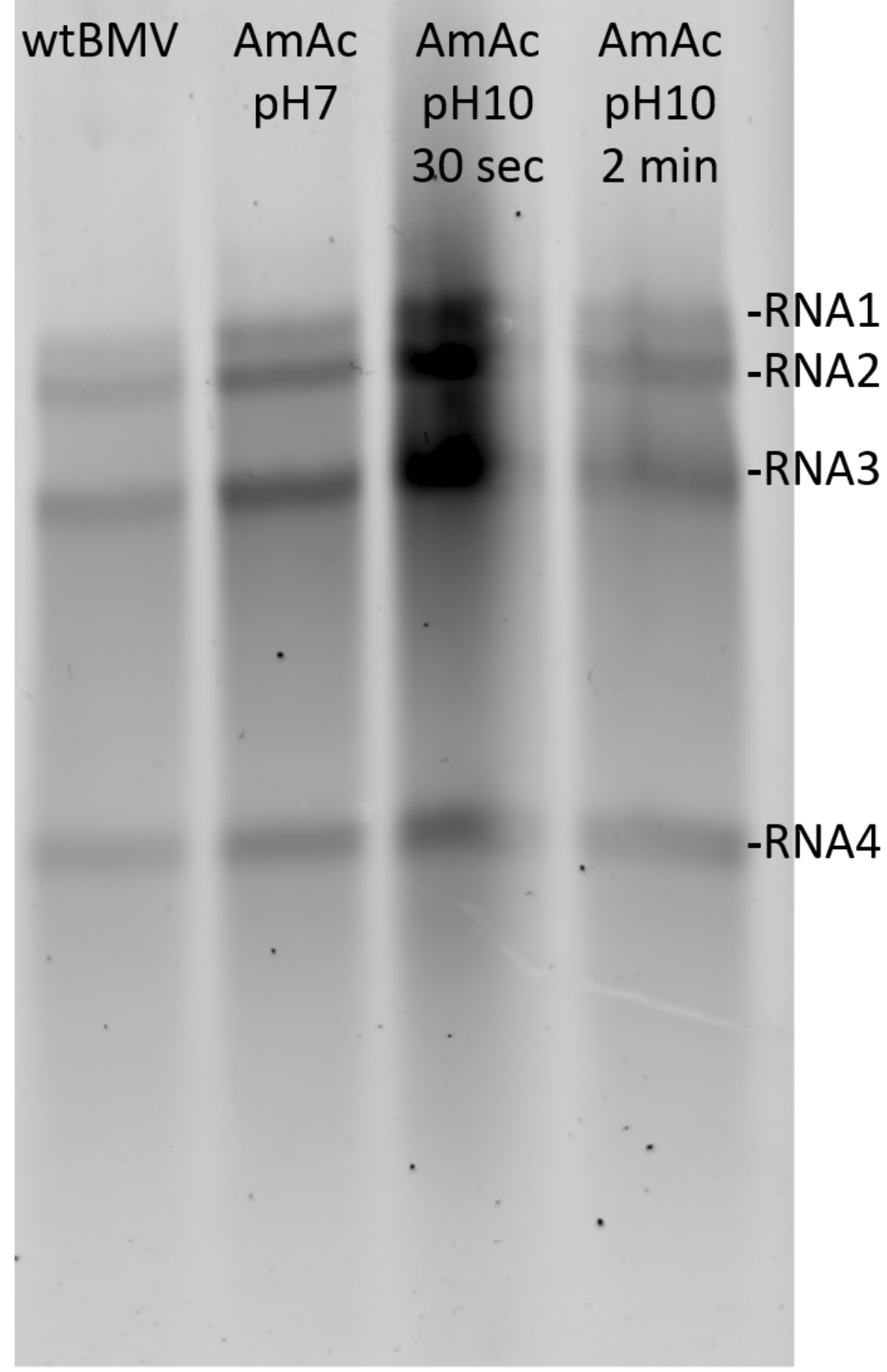


Table S1. Examples of $\mathrm{pH}$ values resulting from mixing equal volumes of a solution of ammonium acetate $\left(\mathrm{NH}_{4} \mathrm{OAc}\right)$ at a $\mathrm{pH}$ of 6-7 with a mixture of ammonium acetate with ammonium hydroxide at around $\mathrm{pH} 11$. The ammonium acetate concentrations in both solutions and in the final mixture are the same. As shown in the Table, as the ammonium acetate concentration is increased, the $\mathrm{pH}$ of the mixture increases slightly.

\begin{tabular}{|c|c|c|c|}
\hline $\begin{array}{c}\mathrm{NH}_{4} \mathrm{OAc} \\
\text { concentration, } \\
\mathrm{M}\end{array}$ & $\begin{array}{c}\mathrm{pH} \text { of } \\
\mathrm{NH}_{4} \mathrm{OAc}\end{array}$ & $\begin{array}{c}\mathrm{pH} \text { of } \\
\mathrm{NH}_{4} \mathrm{OH} \\
\text { and } \\
\mathrm{NH}_{4} \mathrm{OAc}\end{array}$ & $\begin{array}{c}\mathrm{pH} \text { after } \\
\text { mixing 1:1 }\end{array}$ \\
\hline 0.01 & 6.6 & 10.99 & 10.25 \\
\hline 0.05 & 6.6 & 10.95 & 10.44 \\
\hline 0.1 & 6.8 & 10.98 & 10.58 \\
\hline
\end{tabular}

